\title{
Economic Ideology and the Federal Judicial Task
}

\author{
The Federal Courts: Crisis AND Reform; by Richard A. \\ Posner.† Cambridge: Harvard University Press, 1985. Pp. xvii, \\ 365. $\$ 25.50$
}

Reviewed By Jonathan D. Varat $\ddagger$

Richard Posner has produced an ambitious "institutional analysis" of the federal judicial system in which he now officially participates (p. 322). Its reach is better reflected in the broad, if less catchy, title of the book ("The Federal Courts") than in the subtitle ("Crisis and Reform"). Though a inajor portion of the book (chapters three through five) analyzes the dramatic expansion of the federal court caseload in the past twenty-five years and assesses a wide variety of "reform" proposals aiming to alleviate the caseload "crisis," the work as a whole ranges far beyond these topics.

Posner begins with two chapters analyzing the federal court systen 1 as an economist or sociologist might study an industrial organization. He describes the systeni's functions, the deniand for and supply of its services, its hierarchical and pyramidal organization, its personnel, and its jurisdiction. He addresses the caseload crisis and "palliatives" designed to cure it in the next three chapters, but the second half of the book branches out in several different directions. Chapter six elaborates an economic and political theory of federalisn as a basis for reconsidering the optimal use of federal courts. Chapters seven through ten present essentially normative arguments for ways to improve the quality of judicial performance wherever federal jurisdiction is retained. Here, Posner argues for judicial self-restraint to reduce federal court power, nore institutional and less individuahistic judicial opinions, statutory and constitutional interpretation inore sensitive to legislative compromises when text and history are not determinative, and the systeniatic use of economic analysis in judging (pp. 220-21). A concluding chapter calls for more social science research into legal institutions to be performed in the law schools $^{1}$ and for new law courses im judicial administration, opinion writ-

$\dagger$ Judge, United States Court of Appeals for the Seventh Circuit.

$\ddagger$ Professor of Law, University of California, Los Angeles. B.A. 1967, J.D. 1972, University of Pennsylvania.

1. Posner recognizes that there are substantial "barriers to integrating social science into the law schools" (p. 330), including lack of student interest "in the scientific study of the legal system" (p. 327) and the dominance of "doctrinal analysts" on law school faculties (p. 327). He nonetheless believes a "university environment" is needed for quality research in judicial adninistration (p. 330). 
ing, and legislation. ${ }^{2}$

Posner intends an "eclectic" approach, einploying "economic and pohtical theory, statistics, and history, as well as the traditional methods of legal analysis" and to a lesser extent, his personal "experience as a federal court of appeals judge" (p. vii). His predominant focus is nonetheless economic. American law, he believes, is dominated "by utilitarian, pragmatic, 'free enterprise,' and 'balancing' thinking, all of which $\ldots$ is a lay version of . . . economics viewed broadly as the science of rational choice" (p. 315). Viewed this broadly, econornics may mean only that utilitarian decisions should take account of all relevant considerations, mcluding those that other disciplines highlight. Posner's overarching metlod, lowever, is the cost-benefit analysis. This approach focuses on factors sucli as demand and supply adjustments, incentive structures, substitutes or alternatives, and externalities, among other valuable tools of economic analysis.

A book about so many facets of the federal courts as a legal institution risks a loss of focus and colherence, especially when it is simultaneously descriptive, quantitative, and analytic on the one hand, and normative, speculative and theoretical on the other. A loss of focus perhaps is inevitable considering the broad audience that Posner attempts to address: "lawyers and judges, ... economists, lisstorians, public administrators, and others who inay liave significant contributions to make to miproving the federal courts" (p. vini). Posner attempts so much in this book that he may be spreading himself as thin as the federal judiciary that he finds is suffering a workload crisis, with the same attendant risk of a decline in quality of performance. He succeeds admirably in establishing an agenda of issues, but is much less successful in justifying his jurisdictional and qualitative proposals.

The numerous vantage points from which one might choose to review sucli a multifaceted work necessitates a selection process that, ideally, will do justice to the author's effort. This Review evaluates six major strands of Posner's work: 1) his systemic, institutional analysis of the federal courts as providers of judicial services and of the caseload growth phenomenon; 2) proposals to deal witl the increased demand for judicial services; 3) Posner's theory of federalism; 4) lis prescriptions for lessening the quantity and improving the quality of federal judicial decisionmaking; 5) the parameters that bound Posner's vision of the federal

2. Posner suggests a course on opinion-writing to recognize law clerks' increasingly important role in drafting opinions for judges (pp. 102-19, 335). His suggested course on legislation would cover the process of enactment (including empirical studies of who does the drafting and how Congress responds to judicial interpretation), techniques of judicial interpretation (especially the "debunking literature on the canons of construction"), and methods for researching legislative history (pp. 337-39). 
courts' role in the lawmaking process; and 6) his use of economics and social science to analyze the federal judiciary.

\section{I}

\section{POSNER's INSTITUTIONAL ANALYSIS AND THE CASEloAd CRisis}

Posner systematically and comprehensively examines the extent, causes, and effects of the demand growth experienced by the federal courts in the last twenty-five years, and assesses possible responses. His "economic model of adjudication" (p. 322) is based on federal court provision of three judicial services: dispute resolution, law creation, and judicial review (pp. 1-7). Potential demand for these services depends on the scope of statutory jurisdiction, the rules of justiciability, and the extent of substantive rights the federal judiciary creates or enforces (pp. 47-55, 77-80). The frequency with which litigants actually will seek to invoke available federal jurisdiction, on the other hand, depends on the extent of the population's activities, their estimated success in litigation, litigation costs, the availability of an attractive state court substitute, and the availability of attractive substitutes for litigation-including arbitration or settlement (pp. 7-10, 77). The supply of federal judicial services may be rationed through price increases or delays in delivery, or expanded througl increases in the institution's productive capacity (pp. 10-11, 94-97).

Posner provocatively applies this theoretical framework of institutional demand and supply characteristics to account for the aggregate increase of $250 \%$ in district court cases and $686 \%$ in courts of appeals cases since 1960 (p. 65). In the 1920's and 1930's, Prohibition alone caused a steep rise in criminal and civil cases in the federal courts (pp. 60-61, 76). The causes of the post-1960 caseload growth, however, are more complex (p. 92). Growth in population and economic activity is not necessarily the answer (p. 77). Rather, Posner argues, the caseload growtl is attributable to a lowering of demand barriers (p. 77). For example, providing indigents witl free counsel lias reduced price impediments (p. 79). Inflation las sapped the capacity of the $\$ 10,000$ amountin-controversy requirement to screen out diversity cases (pp. 78-79), and that requirement lias been eliminated in federal question cases (p. 79). Courts have relaxed justiciability barriers (p. 79), and the courts and Congress have created new express and imphed federal rights (pp. 80, 83). ${ }^{3}$ A similar expansion of state law rights partially may account for

3. Diversity filings also may have increased because federal courts are perceived to offer more attractive procedural rules, and more able and impartial judges (pp. 46-47, 55, 144). Apparently, "federal courts are becoming more attractive to diversity defendants" on removal, as well as to diversity plaintiffs (p. 86). 
the threefold increase in diversity cases (p. 86). Both regulatory activity and deregulation have produced substantial judicial business, especially in the courts of appeals (p. 84). Uncertainty about the law not only has proinoted hitigation over settlement (p. 10), but also has fostered a higher rate of appeal (pp. 91-92). Appellate review of federal criminal sentences may further exacerbate the caseload crisis (p. 92$),{ }^{4}$ but, in general, the rate of future caseload growth cannot be predicted confidently (p. 93).

Posner also finds that supply has not been restricted to curtail demand. Congress has avoided raising the price of judicial services (p. 95), and there has been hittle increase im docket delay since 1960 (p. 96). Instead, the system has been enlarged "to whatever size is necessary to meet the demand for its services" (p. 96). While the near-doubling of federal court judges in this period did not match the caseload increases, supply also expanded through growth of a parajudicial bureaucracymore law clerks, externs, staff attorneys, magistrates, and bankruptcy judges (p. 97).

Posner worries about this exclusive rehance on expanding supply, because it threatens the quality of the federal judges' work in a variety of ways. Creating more judgeships reduces the prestige of the job (p. 99) and makes each judge a less visible, less accountable part of the system (p. 21). Increasing the support staff, particularly the number of law clerks, ${ }^{5}$ diverts judges from writmg their own opinions to supervising the writmg of others (pp. 103-04). This makes the job less attractive to superior candidates (p. 116). It also inhibits the developinent of great judges, who must create, not adopt or edit, their opinions (p. 111). Moreover, reliance on the "judiciary's own ghostwriting bureaucracy" (p. 116) lowers the quality of opinions by promoting styhistic uniformity, undue length, lack of candor, inadequate research, and excessive citations (pp. 107-10). These ill effects undermine the credibility of opinions and may increase mcentives to hitigate by creating uncertainty in the law (p. 110).

Factors other than institutional size affect the quality of the federal judicial product too. Excessive workload has resulted in curtailment of oral argument (p. 119), limited publication rules resulting from lower quality opinions (pp. 120-26), and increases in per curiam and "nonreasoned" or conclusory separate opimons (pp. 126-29). The qual-

4. This became a reality with passage of Title II of the Comprehensive Crime Control Act of 1984. See 28 U.S.C.A. $\S \S 991-98$ (West Supp. 1985) and SENATE Comm. ON Appropriations, Comprehensive Crime Control ACt of 1984, S. Rep. No. 225, 98th Cong., reprinted in 1984 U.S. CODE CONG. \& ADMin. NEWS 3182, 3220-373.

5. "Law clerks ... are the proximate cause of the enormous increase in the federal judicial output of separate opinions, footnotes, citations, and above all words" (p. 115). As the number of clerks has increased, so has each judge's number of opinions and words per opinion. Most dramatic is a 50\% increase in Supreme Court opinions and tripling of words in those opinions between 1969 and 1972, "the period during which the Justices each became entitled to a third law clerk" (p. 114). 
ity of federal judges, a key variable, largely depends on selection criteria and recruitment inducements. Political patronage is the predominant selection criterion; merit and ideology play a lesser role (pp. 29-31). ${ }^{6}$ Inducements to take the job include pay, power, imdependence, status, and rewarding work. The last two suffer with mcreased workload and Congress's failure to augment judicial salaries to keep pace with inflation has aggravated the situation (pp. 36, 41-42). Adherence to a geographically uniform salary structure has further harmed recruitment in regions where the cost of living is high (p. 43). Moreover, federal judges, once appointed, have no incentives to perform well in order to achieve job security or pay increases (p. 16), and their prospects for job promotion are limited. On the other hand, the assistance of law clerks, who are chosen on merit, and judges' concern for maintaming status and avoiding criticism (pp. 21-22), may raise the quality of adjudication. ${ }^{7}$

Finally, the constraints of the federal court system as a whole play a significant part. Posner views the pyramidal, three-tiered structure as an efficient, nearly inevitable arrangeinent to supply the services demanded of courts (pp. 11-13). The single trial judge is primarily a disputeresolver (p. 12). The appellate courts are primarily providers of consistent legal rules, and two appellate tiers have developed only to sliare the otherwise overwlielming burden of law creation (pp. 11-13). ${ }^{8}$ But while expanding the number of district judges would provide inore disputeresolving capacity, the requirement of consistency im creating legal rules inherently limits the value of adding more appellate judges (pp. 14, 99). Enlarging the support bureaucracy is thus inore likely than imcreasing the nuinber of appellate judges, an unpleasant specter for Posner.

Posner einphasizes methods of limitimg deinand for federal judicial services rather than expanding their supply (pp. 129-31, 317-21). ${ }^{9}$ His mission is quality control. His plan is to eliminate excessive workloads and to improve federal judicial compensation, attitudes, methods, and approaches.

6. Posner understates the ideological component of appointments below the Supreme Court level, especially the appointments of President Reagan. See Judging the Judges, NEwsweEk, Oct. 14, 1985, at 73 (Reagan Administration uses a formalized, high-level process to screen potential federal court nominees "for ideological irregularity").

7. The likelihood of appoimtment to the Supreme Court is quite small, but Posner does make clear that "merit often plays a larger role in appointing district judges than nonjudges to the courts of appcals" (p. 45 ) and that "about 40 percent of the circuit judges come" from the ranks of district judges (pp. 229-30).

8. Because the courts of appeals and the Supreme Court perform the law creation function, "once there is an intermediate court, then quite apart froun workload it makes sense for the supreme court to exercise a discretionary rather than mandatory jurisdiction" (p. 13).

9. Although price rationing and delay are discussed as supply-side responses, if adopted they would act to discourage deinand. Posner's real aim is to deemphasize supply-expanding responses and focus attention on demand-contracting responses. 
Posner's diagnostic framework is impressive and useful. His specific diagnosis of the caseload explosion contains important information and imsights. But lis analysis is incomplete, vulnerable, and based on debatable value judgments that deserve frank acknowledgment.

First, the selection, recruitment, and working conditions of federal judges seem more complex, and the relevant factors more incompatible with each other, than Posner suggests. Posner is concerned that salary inadequacies make successful law-firm practitioners less interested in federal judgeships. ${ }^{10}$ On the other hand, practicing lawyers may be better suited and more attracted to the increasingly supervisorial work of federal judges that Posner decries (p. 105). The inherent systemic restraints on federal judges' power and the increased self-restraint Posner urges may, like inadequate salaries, make the position less attractive to politically disposed candidates with reahistic chances of appointment. Posner barely acknowledges that power, as well as pay and status, is a recruitment incentive (pp. 31-32). His emphasis on financial incentives contrasts sharply with lis neglect of power incentives. A more comprehensive study would systematically examine how the overall mix of inducements to seek federal judgeships has changed over time and what, if any, effects those changes have had on the composition and quality of the recruitment pool.

Less globally, I doubt that the caseload explosion threatens to deprive us of the occasional "great judge" (p.111). Posner is very taken with the role of the great judge, especially Holmes, ${ }^{11}$ and therefore is concerned about the potential loss, or failure of emergence, of such an individual. Is it really likely, however, that people with those kinds of innate capacities, functioning over the course of a long career, will fail to make their creative contributions simply because the need to process caseload promotes managerial and editorial responsibilities?

Posner's preference for quahty over quantity, for keeping the federal judiciary an ehite institution, runs deep. One might have expected a devotee of econormic analysis to suggest a self-correcting inechanism by wlich litigants would redirect their demand to alternative forums whenever the demands on the federal court system cause a sufficient decline in

10. He cites evidence that the pay cut successful urban practitioners must take to become federal judges has indeed resulted in many "federal judges generally ... not being appointed from the very top rank of the practicing bar, but from just below the top" (p. 41).

11. Posner admires Holmes for his realism, social darwinism, skepticism, and commitment to judicial self-restraint. Holmes acted consistently along social darwinian lines when he drew on his individualistic, antisocialist philosophy in areas of private judge-made law, but "subordinated [it] to considerations of judicial self-restraint" when asked to review the validity of even redistributive legislative experimentation (p. 215). The marketplace of ideas must be permitted to thrive, and legislative decisions to accept some of them must be permitted to operate. Both ideas are "Darwinian" (p. 221). 
the quality of its output. ${ }^{12}$ Instead, his approach is to assume that the federal court product should remain the Rolls-Royce of adjudication, and that understandable demand for the better product should be controlled.

Moreover, the conception of "quahty" that Posner favors promotes values that slight distributional concerns. It prefers better decisions in a narrower range of cases to incrementally inferior decisions im a broader range. We might well think that the quality of justice would be better served, however, if federal courts did more sliglitly less well than too httle extremely well. There can be, im other words, a quahtative dimension to quantity. The tradeoff between quality and quantity is not necessarily, as Posner assumes, a one-way street pointing towards ehte adjudication and away from more broadly distributed federal court justice.

From a less ehte perspective, some of the other phenomena Posner examines also look somewliat different. For example, the relaxation of justiciability barriers may be seen as a sensible means of facilitating the law creation function and of providing federal court justice for more people. Similarly, the substantive expansion of federal rights by Congress and the Supreme Court, while mcreasing judicial busmess, also embodies a conscious judgment that broadening of the category of rights given legal protection will improve the quality of society. ${ }^{13}$ Increasing the availability of lawyers for indigents and declining to use price to ration federal court access reflect kindred judgments.

An optimial mix of quality of decision and breadth of availability must rest on a set of agreed social objectives. The tradeoff between quality and quantity renains, but Posner's preferences for deregulation over regulation and for ehte decisionınaking over distributional considerations require justification. We must know whether losses of one are outweighed by gains in the other, taking into account the social value the pohity attaches to each. These sorts of judgments are relevant not only to assessing how well the extant federal judicial system balances quality and quantity, but also to assessing wliat kinds of reforms are appropriate

12. Posner does invoke Adam Smith's "invisible hand" analysis in a less obvious context when he speculates that "swings in the settlement rate should be self-correcting" (p. 10). His idea is that lack of information encourages litigation, which produces information needed for further settlement, which then decreases the need for more litigation. Posner later urges government correction of the rate of litigation and settlement, not litigant self-correction (p. 321).

13. This does not mean, of course, that more explicit focus on the workload effects of newly created claims along the lines of Chief Justice Burger's proposals for "court impact statements" would be undesirable. See Chief Justice Burger's 1977 Report to the American Bar Association, 63 A.B.A. J. 504, 505 (1977); Burger, The State of the Federal Judiciary-1972, 58 A.B.A. J. 1049, 1050 (1972); Judicial Impact Statements, WASH. PosT, Feb. 15, 1977, at A14, col. 1. Taking account of the value of new federal rights and the increased burdens their enforcement will place on the federal courts is preferable to decisionmaking that ignores one or the other. 
when there is widespread agreement that quantitative adjustments are necessary.

\section{II}

\section{What to Do About Case Overload}

Assuming Posner is right that we should control demand rather than further expand supply, what methods are available and which should be preferred? Posner first evaluates a moderate group of reform proposals- "palliatives"- that promise hittle "more than a limited and temporary effect" on caseload (p. 131). He then undertakes a "consideration of fundamental reform" (p. 169), developing a theory of federalism to derive the optimal scope of federal jurisdiction. Finally, he discusses changes $\mathrm{m}$ judicial method to reduce caseload and enhance the quality of federal court decisions.

Posner's palliatives include those "that have soine prospect of adoption ... in the foreseeable future" (p. 130). The first set involves price rationing, which represents a departure from the seemingly "unshakable commitment to accommodating any increase in the demand for federal judicial services without raising the[ir] price" (p. 95). Posner would impose moderate user fees to discourage nonindigents from suing in federal court uuless they find the supposedly higher quality adjudication worth the price (pp. 131-36). He also supports two-way fee shifting of attorneys' fees for nomindigent hitigants. He suggests this be done experimentally in diversity cases or by allowing recovery of attorneys' fees whenever the losing party was not "substantially justified"14 in its litigating position (pp. 136-38). He shies away from recommending total abolition of diversity jurisdiction (pp. 146, 176-77), but advocates limiting it by raising the minimum amount in controversy to $\$ 50,000$ and forbidding residents to invoke it (pp. 146-47). Currently, diversity jurisdiction accounts for twenty percent of case filings in the district courts and nearly fifteen percent of the courts of appeals' dockets (p. 64). About half of all diversity cases are invoked by residents (pp. 146-47). Posner also would remtroduce minimum amount-in-controversy requirements in federal-question cases as a fallback position to imposing user fees (p. 139).

Posner opposes supply-expanding proposals to create new federal courts speciahized by subject matter, except for a court of tax appeals ( $p$. 160). Specialization, Posner argues, threatens to reduce job satisfaction and the quality of the judges (pp. 150-51). The ideological component of appellate judging also limits the value of specialists (p. 151). Specialized

14. The standard is borrowed from the Equal Access to Justice Act, 28 U.S.C.A. $\S 2412$ (d)(1)(A) (West Supp. 1986). 
courts, which decide a narrow range of issues, are more easily dominated by one ideology (p. 152) and controlled by the President and Congress through appointments and appropriations (p. 154). Specialists are less likely to provide a diversity of ideas and approaches (pp. 156-57). Further, because geographic diversity and the "cross-pollination of legal ideas" will be reduced (pp. 156-57), jurisdictional issues may increase. Finally, generalized courts are better able to cope with "unforeseen changes in the caseload mix" (p. 157).

Posner favors strengthening the appellate process within the federal administrative agencies to reduce the need for judicial review of agency decisions (p. 161). He opposes creation of a new appellate court between the courts of appeals and the Supreme Court (pp. 162-66). He is doubtful that uniform resolution of more intercircuit conflicts is preferable to "diversity and competition" (p. 163). He thinks the Supreme Court is responsible for some of its own workload difficulties and that staffing the new court with current courts of appeals judges would only create more work for these already overloaded people, who would have no greater insight than the judges whose decisions they were to review anyway (pp. 165-66). Posner beheves that much of the conflict problem could be eliminated if the courts of appeals deferred whenever three other circuits previously have decided an issue the same way (p. 165).

Many of the reforms Posner advocates rest on two potentially objectionable premises. The first is that federal courts should use price as a caseload regulator. ${ }^{15}$ The second is that redirecting some federal-question cases to state courts is not undesirable, despite the presumptive sacrifices of quality, expertise, and uniformity of federal law decisions. Posner is indifferent to this reallocation because where others see desirable uniformity in federal court decisions, he sees monopoly (p. 163). Where others see conflict between federal and state court decisions, he sees desirable competition (p. 163).

Posner's advocacy of price rationing is most controversial. His arguinent for user fees begins froin the wholly accurate observation that those who hitigate are subsidized by the many taxpayers who do not (pp. 10, 131-32). Nonlitigants benefit because itigation creates legal precedents that allow otlers to settle disputes without litigation (p. 10). Posner concludes that while the externalized nuformational benefits of litigation do justify some subsidy to litigants, they do not justify the vast public subsidy that keeps court fees at their present level (p. 132). Posner advocates a small rise in user fees to reduce the taxpayer subsidy a little, not fully, in order to reduce overall demand for federal court litigation

15. Posner does not consider deliberate delay of litigation to regulate caseload a serious option because delay distorts accurate decisionmaking through decay of evidence and makes legal obligations uncertain. These disadvantages outweigh the ueed to limit caseload (p. 139). 
(p. 136). This will help assure higher quality hitigation and decisionmaking in the federal courts, because those willing to invest more resources to gain federal court access will be inore likely to protect their investinents (pp. 132-33). The higher quality federal product will make up solnewliat for the lower quality adjudication of cases the user fees divert to the presunptively less able state courts (p. 135). Nonlitigants will benefit as well through the trickle-down effect of better precedents (p. 134). In sliort, the proposal would inove middle-class litigation to state court and reserve the federal courts for higher-stakes cases and those brouglit by indigents.

The distributional preferences einbodied in the scheine are perhaps of inore interest than the practical effects, which seen limited unless tlie user fee becoines very high. The taxpayer subsidy presuines that federal judicial services are a public good, one whose value extends beyond litigants and nonlitigants interested in legal rules to society as a wliole. Legal rules not only keep dispute resolution peaceful, but also provide cohesion and integration in a just social order. The justification for litigant user fees is weakened if we acknowledge that tliose who never litigate and even liave no litigable disputes nonetheless are societal users of the judicial system. ${ }^{16}$

Moreover, inany claims litigated in the federal courts lave public law dimensions that inake uniform, expert, and higli-quality decision desirable. Every federal-question case shunted froin federal to state court risks undercutting these objectives. True, some already arise in state court, and Supreine Court appellate review nuay be available. But before we impose user fees, or reverse the policy of inaximizimg uniform treatinent that led to abohishing amount-in-controversy requirenients in federal-question cases, ${ }^{17}$ we should be sure that we share Posner's preference for diversity ("competition") over uniformity ("inonopoly") and that we are prepared to accept the quantitative loss of higlier quality federal adjudication that Posner's distributional scheme inplies.

If we inust cut cases froin the federal court docket, we should evaluate all the available criteria for excision. Is it better to use financial criteria than to determine what whole categories of cases, such as diversity cases, are less important to us, so tliat we are prepared to tolerate tlie incrementally inferior quality of adjudication we presuine they will

16. This is not to say that the financial importance of litigation is wholly irrelevant to the allocation of scarce federal court resources, although financial importance may be identified more directly by minimum amount-in-controversy requirements than by user fees.

17. The requirement was eliminated in suits against the United States, its agencies, or officials in 1976, Act of Oct. 21, 1976, Pub. L. No. 94-574, 90 Stat. 2721, and altogether in 1980, Federal Question Jurisdictional Amendments Act, Pub. L. No. 96-486, 94 Stat. 2369 (1980). For a summary review of the progressive narrowing of the jurisdictional amount requirement in federal question cases, see C. WRIGHT, The LAW OF FEDERAL Courts 176-81 (4th ed. 1983). 
receive if turned away from federal court? These are, of course, political value judgments with practical, institutional, ${ }^{18}$ distributional, and "constitutive"19 imphications, just like those that he behind Posner's acceptance of the need to exempt indigents from user fees.

Similar considerations he behind fee-shifting arrangements as a way to discourage hitigation. Even though regulation by price is only one of Posner's suggestions for reducing federal court demand, it is hardly value-neutral. The particular set of values it embodies deserves thorough deliberation before deciding that we want to push the federal courts toward more financially elite litigation.

Posner's second pervasive value-tolerance of nonuniform decisions-also deserves careful appraisal. It not only underhies his price rationing proposals, but also his opposition to an intercircuit tribunal and to more subject-matter specialization in federal appellate courts. ${ }^{20}$ There is considerable unacknowledged tension between Posner's preference for diversity of decisions and his urging elsewhere that judges should act to curb uncertainty about the state of the law because uncertainty contributes to increased higation instead of settlement. ${ }^{21}$ Inevitably there will be a tradeoff between how many voices will be allowed to speak to an issue (and how often) and the clarity or definitiveness with which the system as a whole speaks. There is also an inevitable tradeoff between the competitive advantages that may accrue if state and federal courts decide the same kinds of cases and the ability to secure effective, uniform enforcement of fundamental legal norms. The search we must make is for the optimal balance between these two benefits. This, too, mvolves political judgments. Is more uniformity desirable at the risk of greater concentration or is more diversification desirable at the risk of ineffectiveness? Posner's arguments against appellate specialization may be powerful, but his advocacy of nonuniform decisions overall is unappealing.

III

POSNER's THEORY OF FEDERALISM

Moving from palliatives to "consideration of fundamental reform"

18. For an approving view of taking account of institutional values in adjudication, a view that seems equally relevant to legislative determinations, see Newman, Between Legal Realism and Neutral Principles: The Legitimacy of Institutional Values, 72 CAL1F. L. REV. 200 (1984). Posner, too, as the author of an "institutional analysis," sometimes emphasizes institutional values (p. 258).

19. See Tribe, Constitutional Calculus: Equal Justice or Economic Efficiency, 98 HARv. L. REV, 592, 606-14 (1985).

20. Fear of concentrated legal power in a small number of courts also appears to underlie Posner's opposition to broad holdings (p. 257) and his conclusion that "the second court should decide the breadth of the precedent created by the first" (p. 250).

21. It is also at odds with his preference for adoption of rules rather than multifactored standards (pp. 245-47). See infra text accompanying notes 38-39. 
(p. 169), Posner proposes a theory of federalism that suggests the optimal bounds of federal jurisdiction. He concedes that his theory would not "have revolutionary implications for reallocating federal judicial business to the state courts" (p. 189). ${ }^{22}$ Its primary value is to derive "an ideal allocation of lawmaking responsibilities between the states and the federal government" (p. 175).

Posner's theory is couched largely in economic terms: monopoly, competition, externalities, econormes of standardization, and diseconoimies of scale. He characterizes federal regulation as monopolistic, because there is effectively no alternative legal regime when our one central government acts. By contrast, state regulation is competitive, because each state offers an alternative regulatory regime from which to choose. He generally prefers state regulation over federal in order to avoid disecono1mies of scale and the inefficiency of giant national bureaucracies, and to permit experimentation with diverse laws that will produce valuable policy information (tlie familiar "states as laboratories" argument) (pp. 173-74). He finds an independent federal judiciary justified to check monopoly federal power. ${ }^{23}$ He sees less need for federal judges to control state power, because citizens more easily may migrate to escape burdensome state regulation, giving states a competitive incentive to refrain from regulatory abuse (pp. 172-73). Posner argues that independent federal jurisdiction to check state authority is justified, however, when economies of standardization make uriform federal rules efficient and when the riglits of nonresidents or "pohitically disfavored" residents are unlikely to be protected by pohitically accountable state judges.

As apphed, Posner unacceptably limits the implications of his theory for the scope of federal jurisdiction. He is most persuasive in developing the argument that federal judges' relative independence from state political forces justifies their autliority to adjudicate cases threatening interstate externalities such as pollution, nonresident interests in diversity cases, suits against the United States, and federal criminal laws based

22. Posner does claim that his analysis yields "the conclusion that the federal courts" jurisdiction should ... be curtailed relative to that of the states" (pp. 191-92). Elsewhere, he simply asserts that "some redress of the balance of power between federal and state courts is long overdue" (p. 135).

23. According to Posner, the same independence that provides a judicial check against the monopolistic power of the other branches of the federal government also entails "insula[tion] from the usual incentives to efficient performance" (p. 173). It seems doubtful that federal judges are less efficient than their less insulated state counterparts, however, or even than they would be were they not so insulated. Perhaps other incentives neutralize the independence point in this context. To name just a few, a felt sense of professional responsibility, peer pressure from other judges, the demands of hitigants, or the desire to exercise power frequently, might spur a federal judge to behave efficiently. 
on interstate effects. ${ }^{24}$ Conversely, he suggests, the interstate externality justification does not support federal jurisdiction in cases posing no risk of harm to nonresident interests, whether based on diversity or federal statutes. ${ }^{25} \mathrm{He}$ also presents a convincing argument for federal admiralty jurisdiction based on economies of standardization. Posner argues that the efficiency of having only one body of procedural and substantive law governing inaritime businesses that do intermittent business in multiple jurisdictions does not extend to "incidents involving purely doinestic uses of navigable waterways" (p. 179). He acknowledges, however, that noninaritime enterprises doing business worldwide also have a strong arguinent for one exclusive set of governing rules, an implication of his theory that would expand federal jurisdiction far inore than elimination of doinestic boating cases would reduce it.

The major weaknesses in Posner's theory are his singularly unpersuasive application of the rationale favoring federal jurisdiction to protect pohitically disfavored residents and his failure to acknowledge other miportant reasons for federal jurisdiction. Posner would eliminate federal jurisdiction for age discrimination cases (p. 180), cases brought by state einployees and businesspeople (p. 188), and inany civil rights cases involving minorities, because he beheves "[i]t is no longer true that blacks or Jews or Orientals or even American Indians constitute 'discrete and insular minorities' ... or that these groups lack pohtical power and representation in the judiciary" (p. 188). He views these cases and state prisoner civil rights and federal habeas actions as "[p]otentially the largest area for federal jurisdictional reforin inotivated by principles of federalisin," although unfortunately he says hittle about this provocative assertion (p. 186). He does argue against federal habeas jurisdiction for innocence-related claims, especially claims of insufficiency of evidence to convict under Jackson v. Virginia. ${ }^{26}$ He reasons that state courts are unlikely to be prejudiced against their own innocent, but nay resist enforceinent of constitutional norins that inay benefit the guilty (pp. 187-

24. Posner offers a supplementary justification for federal jurisdiction over some crimes lacking interstate spillover effects. The greater susceptibility of state courts to corrupt factional pressure may warrant federal court enforcement of otlierwise local crimes (pp. 177-78).

25. But see supra note 24. For example, Posner finds no justification for federal jurisdiction in Federal Employers' Liability Act cases, "Truth in Lending cases, odometer-tampering cases, or [local] securities fraud cases" (p. 184). Interestingly, he thinks Textile Workers Union v. Lincoln Mills, 353 U.S. 448 (1957), the case that requires federal courts to develop and enforce a federal common law of labor agreements, is justified on an interstate spillover rationale (pp. 183-84). If the states had control of this area, anti-union states could use labor law to attract business away from pro-union states (pp. 183-84). He also recognizes that fields of "analytical difficulty" and fields where "national uniformity of legal obligation" is important may justify federal jurisdiction (p. 185). Botlı rationales potentially support wide-ranging federal jurisdiction (p. 185).

26. 443 U.S. 307 (1979). 
88). ${ }^{27}$

Posner's assertion that convicted state prisoners and historically disadvantaged minorities are not politically disfavored in state courts today is highly debatable, if not plainly wrong. State courts are not wholly immune to racial prejudice or insensitivity, whether tlieir own or the local community's. Community intolerance of convicted criminals surely inakes thein "politically disfavored" residents at risk in courts susceptible to prejudicial inajoritarian pressure. Indeed, Posner's own suggestion that federal habeas jurisdiction nay be justified to review claims unrelated to innocence is built on the recognition tliat the guilty "enjoy little pohtical favor" (p. 187). The convicted who clain innocence probably do not enjoy much inore favor. Under Posner's own criteria, the political weakness of state prisoners favors retaining federal jurisdiction to review their claims.

Moreover, the policy favoring federal habeas review of innocencerelated claims rests not only on potential state hostility or insensitivity to the claim or the person raising it, but also on the importance of correctly deciding the claim. The value of protecting against wrongful conviction nuay be so high that even if the risk of error is sinall, the desire to prevent it nuay justify federal jurisdiction. ${ }^{28}$ The courts should not preserve "judicial capital" at the expense of "pohitical capital" (p. 209) by turning away innocence-related claims the public is more likely to support in favor of only the least popular claims.

Posner's exclusion of civil rights claims brought by the elderly, state employees, businesspeople, and others who are perhaps not so vulnerable to distorted state court determinations also is problematic. In these cases, the mdependence of federal judges is desirable not so much to protect pohtically weak claimants from class bias, but to ensure effective enforcenient of federal claims that threaten the local status quo. For example, state judges may not favor individual state employees who litigate agamst their government employers. Similarly, independent federal courts may be more willing or able than pressure-prone state courts to enforce changing federal norins, statutory or constitutional, that run counter to entrenched local attitudes, stereotypes, or custoins.

Posner's theory of federal jurisdiction is flawed, then, because it is incomplete. It fails to consider all of the values-political, social, and institutional-that might warrant the use of the presumptively higher quality of federal court adjudication. Posner's theory better justifies

27. His critique of federal habeas jurisdiction is a peculiar inversion of the criticism normally levelled at it. For the usual view, see Schneckloth v. Bustamonte, 412 U.S. 218, 256-58, 265, 274-75 (1973) (Powell, J., concurring); Friendly, Is Innocence Irrelevant? Collateral Attack on Criminal Judgments, 38 U. CHI. L. REV. 142 (1970).

28. This is the primary basis for Jackson v. Virginia, 443 U.S. 307 (1979). 
inclusion of some subjects in federal jurisdiction than exclusion of others. That might suffice for some theoretical enterprises, but not for Posner's. His theory aims to reserve the limited resources of the federal court system for the cases where they are most needed. Such a theory, to be fair and rational, must first take full account of all appropriate claims for federal jurisdiction before settimg priorities among them. Posner's partial account demigrates the strength or existence of some claims and skews the establishment of priorities. ${ }^{29}$

IV

\section{PRESCRIPTIONS FOR QUALITY CONTROL}

Most of Posner's proposals to pare down federal jurisdiction discussed so far are directed to Congress. ${ }^{30}$ Four chapters (seven through ten), however, propose reforms the federal judges can implement themselves. The first two urge greater self-restraint in reducing federal court power over other government officials and changes in "judicial technique" and "craft" (p. 223). ${ }^{31}$ Posner views judicial self-restraint as the "substantive pohtical primciple" (p. 207) that judicial power should be reduced relative to other branches of government. Other conceptionsdeference, adherence to stare decisis, avoidance of the use of personal policy preferences, and taking account of political or caseload limitsshould not be confused with this notion. Posner argues that the preferred conception, called "structural restraint" (p. 208), is a valid and important, if also "contimgent, ... time-and-place bound" (p. 211), primciple of adjudication. It is, however, but one among many factors of "responsible judicial decision making" (p. 220) in those cases where "a judge caunot decide ... simply by reference to the will of others-legislators, or the judges who decided previous cases, or the authors of the Constitution" (pp. 206-07).

Posner hopes to persuade federal judges that structural restraint will help alleviate the caseload crisis to which the "courts' self-aggrandizement" has contributed (p. 210). Moreover, Posner beheves that "contemporary activism" risks too much "projection of the judge's will" (p.

29. Henry Monaghan's review of The Federal Courts sounds a similar theme, finding Posner's "jurisdictional analysis . . . incomplete," primarily for failing to take account of "limitations on federal judicial intervention in state affairs" and "to give any meaningful account of potential noneconomic bias agaiust federal policy in the state courts." Monaghan, Taking Bureaucracy Seriously (Book Review), 99 HaRv. L. REV. 344, 350, 352 (1985).

30. The scope of federal habeas jurisdiction, however, has expanded and contracted at the hands of the Supreme Court without congressional amendment. See Wainwright v. Sykes, 433 U.S. 72,81 (1977) (openly acknowledging the "Court's historic willingness to overturn or inodify its earlier views of the scope of the writ, even where the statutory language authorizing judicial action has remained unchanged").

31. The last two, discussed in Part V, urge a particular approach to statutory and constitutional interpretation and increased use of economic analysis. 
215). Judicial activism also lacks candor, a quality "more congenial to the restramed than to the activist judge" (p. 218).

It is difficult to tell how critical a factor Posner intends structural restraint to be. Insofar as it aims at significant caseload reduction, a strong principle might well require alteration of the nature of the judicial role. Substantially less weight would necessarily be given to the checking function, particularly the antimajoritarian function, of the federal courts. ${ }^{32}$ For Posner, caseload considerations and a desire to curb judicial power both point towards more restraint. In fact, the latter must be more important to Posner, because he rejects a directly caseload-sensitive conception of restraint. Others, however, think the federal courts should curb government overreaching more frequently. ${ }^{33}$ For them, any caseload reduction benefits of structural restraint are an undesirable tradeoff against the loss of the federal courts' policing function.

Posner's own analysis suggests, moreover, that structural restraint may aggravate rather than imitigate the caseload crisis. He notes that mcreasing caseload accompanies periods of legislative deregulation as well as regulation, at least im the short run (p. 84). More generally, changes in law produce hitigation that test the nature and scope of the transition. The point applies equally to periods of federal judicial deregulation of government action. Decreasing the power of federal courts will require hitigation to locate just where the new and less activist line will be drawn. Caseload considerations thus may conflict with changes in the level of structural restraint. One begins to suspect that the caseload crisis has hittle to do with Posner's attachinent to structural restranit.

It also is unclear how structural restraint applies to cases in which federal courts potentially must decide whether to reach the merits in the first place, and, if so, whether to invalidate challenged governinent action. Posner clearly would have federal courts refrain from striking down the actions of other government branches. Would he also have them refrain from asserting the authority to review those actions? This question is significant because the Burger Court occasionally seemed to avoid justiciability obstacles, and barriers to review of state court decisions, im order to validate government conduct. ${ }^{34}$ That practice simulta-

32. Posner acknowledges this point, stating, "but of course if self-restraint is carried too far the courts will cease to play their appointed role in the system of checks and balances" (p. 214). He leaves unanswered how far is "too far" and what is the extent of the "appointed role" of the federal courts.

33. See, e.g., Neuborne, The Myth of Parity, 90 HARv. L. REv. 1105 (1977).

34. Generous justiciability rulings that led to validation of government policy on the merits include Duke Power Co. v. Carolina Environmental Study Group, Inc., 438 U.S. 59 (1978) and Sosna v. Iowa, 419 U.S. 393 (1975). See generally Varat, Variable Justiciability and the Duke Power Case, 58 TEX. L. REV. 273 (1980). Michigan v. Long, 463 U.S. 1032 (1983), is a noteworthy 
neously increases judicial power to hear challenges of government impropriety and decreases substantive judicial limitations on government conduct.

If Posner's structural restraint principle supports such a practice, it may further undermine the objective of reheving the caseload burden. Phable access doctrines create uncertainty, encourage more cases, and themselves require considerable litigation effort. ${ }^{35}$ Moreover, the active manipulation of access doctrines to achieve structural restraint lacks candor. ${ }^{36}$ It tlierefore undermines Posner's claim tliat admirers of restranit clierish candor more, and are less often forinalist, ${ }^{37}$ thian admirers of activism (p. 220).

Even if Posner would condemn lack of candor in those wlio manipulate access rules to promote substantive structural restraint, his general point is unfounded. Restraint is not superior to activism because its adlierents liave more integrity. Activist judges are often candid about their perception that federal judges should function as interınediaries between government and the rights of the people. Restrained judges sometines refuse to invalidate government action because they fear political or popular disapproval, not because they lionestly think intervention is mappropriate. Candor unay be more difficult for activist judges because their decisions may be disproportionately unpopular, and restramed judges may more easily disguise insincerity witlout using formalist props. But activist judges do not inherently lack candor any more than restrained judges inherently lack courage. As witl all principles of adjudication, restraint or activism may be lonestly or dislonestly invoked.

Posner's proposals to improve judicial teclimique are questionable, too. Most address the quality of opimon-writing. Judicial opinions should provide greater guidance and discourage litigation. ${ }^{38}$ Posner urges judges to make their opinions shorter; to restram egocentric

example of broadening the Court's appellate jurisdiction over state court decisions to uphold the constitutionality of a police search. An example of an overeagerness that backfired is Illinois v. Gates, 462 U.S. 213 (1983) (the Court, having first invited the parties to address whether a good faith exception to the exclusionary rule should be adopted, concluded that the issue should not be decided because it was not presented to the Illinois courts). Certiorari was granted in another case raising the same issue as Gates less than three weeks later, however. United States v. Leon, 463 U.S. 1206 (1983). During the next term the Court approved a good faith exception for police searches, in United States v. Leon, 468 U.S. 897 (1984).

35. See Varat, supra note 34 , at 320 .

36. See id.

37. For an interesting discussion of the meanings and relationships between formalist and instrumentalist jurisprudence, see Note, Formalist and Instrumentalist Legal Reasoning and Legal Theory, 73 Calif. L. REv. 119 (1985).

38. Posner makes limited suggestions that district judges more scrupulously verify the existenee of federal subject-matter jurisdiction, certify appeals less willingly to reduce burdens on the courts of appeals, delegate less work to assistants and magistrates, and control discovery more firmly 
impulses to display learning; to curtail the use of textual footnotes, printed abuse of colleagues, and excessive concurring and dissenting opimions replete with counterattacking references and footnotes (pp. 23040); and to adopt rules rather than multifactored standards to govern disputes (pp. 245-47). He also opposes the creation of broad holdings because judicial foresight is limited, although he supports alternative holdings and dicta for guidance (p. 257).

Posner understates the inherent tradeoffs between certainty and sensitivity to complex circumstances, between clarity and the realities of collective decisionmaking, between brevity and candor, and between brevity and infornation needed for settlement. Indeed, the function of law creation may conflict with the function of dispute resolution. The long, heavily footnoted opimion that responds directly to separate opinions may narrow the majority decision. It also may define areas for further hitigation and provide infornation that bench and bar can use to seek legislative or negotiated solutions. The belabored opinion inay pinpoint value differences among judges that a brief opimion may conceal. Thus, a belabored opinion may be more candid and less fornalist and its premises more easily subjected to scrutmy by the profession and the public.

Short opinions with narrow holdings may provide little sucl guidance. What is not said can cause as much uncertainty as what is said tentatively or obscurely. Because the shape of legal doctrine is only one among many causes of hitigation, those with legal interests in unaddressed issues may have as much incentive to hitigate as they had before the opinion. Moreover, the collectively bargained, unitary opinion, for all its authoritativeness, might necessarily be drafted in a vulnerable or obscure fashion to gloss over differences. ${ }^{39}$ Nor is it clear that discursive opinions drafted by law clerks lack authenticity (p. 255). Finally, Posner's preference for rules over multifactored standards deprecates the value of sensitivity to context and is inconsistent with his concern that judges can call upon only limited foresight. With some issues we will prefer to sacrifice the certainty of bright-line rules and instead weigh all relevant considerations im pursuit of a correct decision, because of the values at stake.

The process of judging, the methods of writing opinions, and the use of precedent are mevitably complex tasks not easily reducible to technical proposals for iniprovement. The connection between the judicial opinion and the uncertamty that foments litigation is especially complex. Clarity

(pp. 225-26). His focus, however, is on law creation in general and the courts of appeals in particular.

39. See, e.g., B. Woodward \& S. ARMStrong, The Brethren 154-56 (1979), discussing Swann v. Charlotte-Mecklenburg Bd. of Educ., 402 U.S. 1 (1971); see also Milliken v. Bradley, 418 U.S. 717 (1974). 
often comes at the expense of well-considered decisions. Choices often must be made between discretion and rules, between discussion and silence, between legal principles that are less certain but more realistically complex and those that are more certain but potentially oversimplified. Posner, a professed realist, unfortunately obscures these choices and oversimplifies the relationships between judicial craft and the caseload crisis. His realism wars witlı his reductionism more tlian lie acknowledges or perhaps realizes.

\section{$\mathrm{V}$ \\ Federal Courts and the Lawmaking Process}

Not all tlie clianges Posner recommends in this book are designed to alleviate the caseload crisis. Statutory and constitutional interpretation and common law adjudication are suffering a "crisis ... of quality alone" (p. 261). Posner's cure is to apply the economic hiterature on the legislative process and the structure of the common law (p. 295) ${ }^{40}$ Posner proposes a two-step metliodology in botli statutory and constitutional interpretation. The judge first should look to whether authoritative guidance exists to decide the current issue and, if it does, should function as "the honest agent of others" (p. 221). If such guidance is not available, because "the will of tlie principals can no longer be discerned," the judge inust "perforce becoin[e] a principal himself" (p. 221).

Posner's realist approach to statutory interpretation is based on the influences that proinpt a statute's passage: public interest, public sentiinent (where utilitarian justifications are not readily available), or the demands of politically effective interest groups (p. 265). ${ }^{41}$ Tle judge

40. Posner doubts, however, that generalist federal judges as currently selected and compensated "can realize the promise of economic analysis of law" (p. 315). His colleague, Seventh Circuit Judge Frank H. Easterbrook, likewise a former law professor at the University of Chicago, also thinks it "unlikely" that judges can "make wise economic decisions routinely." See Easterbrook, The Supreme Court, 1983 Term - Foreword: The Court and the Economic System, 98 HARv. L. Rev, 4, 60 (1984). Cf. Minneapolis Star \& Tribune Co. v. Minnesota Comm'r of Revenue, 460 U.S. 575,590 (1983) ("[C]ourts have little familiarity with the process of evaluating the relative economic burden of taxes.").

Posner further supports the value of economic analysis by presenting an interesting breakdown of issues the federal courts face and demonstrating that cost-benefit analysis is highly relevant to the lawmaking function of federal judges (pp. 296-315). His further claim that judges make law "as if their goal were to promote economic efficiency" (p. 314) does not follow, however. That claim conflates economic cost-benefit niethodology with one substantive economic value-efficiency. Other values may outweigh efficiency and still profitably be examined in cost-benefit terms. More fundamentally, moral judgments play a significant role in adjudication apart from, or despite, efficiency objectives. See Schwartz, Economics, Wealth Distribution, and Justice, 1979 WIs. L. REv. 799.

41. Posner thinks it possible "to classify statutes according to whether they advance the public interest or ... the interest of some (narrow) interest group" (p. 265). He believes that rights of action should be implied more readily from public-interest than from interest-group legislation (pp. 270-72). He also thinks "a realistic understanding of legislation is devastating to the canons of 
should ascertain how the "enacting legislators ... would have wanted the statute applied" (p. 286-87). This method of "imaginative reconstruction" would take account of the legislation's character and what compromises it reflects (p. 287). If this does not yield a result, Posner advocates adhering exclusively to the enacting legislators' conception of reasonableness (p. 287). He rejects Calabresi's proposal that courts discard obsolete statutes even when they are constitutionally perinissible. ${ }^{42}$ Calabresi's view "rests on too tight an embrace of the public-interest conception of legislation" (p. 291).

More fundamentally, Posner views the judicial task as implementing the enacting legislators' product without imcorporating contemporary values. But he also rejects Easterbrook's view that courts simply should refuse to apply a statute that neither expressly resolves the issue nor explicitly authorizes judges to create common law to fill in its gaps. ${ }^{43}$ The political realities of the legislative process produce "incomplete" statutes requiring judicial auginentation "if legislation is to work" (p. 292). Posner purports to seize the middle ground between politically liberal "no constructiomists" who refuse to be bound to the process of original enactment and politically conservative "strict constructionists" who refuse to go beyond the legislation's express coverage. He claims that only his position is constructive and helpful to the legislative process (pp. 292-93).

Posner's two-step approacl to constitutional interpretation builds on botll his realist theory of legislation and his theory of federalism. If the intended ineaning of a constitutional provision is discernible, it must be enforced unless case law firmly establishes a contrary meaning (p. 272). If the meaning is not discernible, or if the provision is designedly open-ended, different considerations should control (pp. 193-97, 273-76). First, the age of inost constitutional provisions inagnifies the need for flexibility, but also increases the incidence of interpretive error. Posner believes it is better to err in favor of majority will than minority claims (p. 272-73). Like Thayer, ${ }^{44}$ he would resolve doubts against claims to restrict government (p. 273). Second, he finds rationality review inappropriate to judge interest-group legislation because it "typically will flunk any test of rationality other than self-interest," and lie finds "no express constitutional riglit not to be disadvantaged by the characteristic opera-

construction" (p. 276) because the canons do not take account of what interests legislation is intended to satisfy. In fact, he attacks many of the canons as remnants of formalism that promote judicial activism by making interpretive choices seem more constrained than they really are (pp. 28586).

42. See generally G. Calabresi, A Common Law for the Age of Statutes (1982).

43. See Easterbrook, Statutes' Domains, 50 U. CHI. L. Rev. 533, 544 (1983).

44. See Thayer, The Origin and Scope of the American Doctrine of Constitutional Law, 7 HARV. L. REV. 129,144 (1893). 
tion of the political process" (p. 274). Third, he seems to oppose strict scrutiny of "public-sentiment" statutes, such as laws regulating sex and obscenity, because they are by nature "not susceptible of utilitarian justification" (p. 275). Finally, even assuming, arguendo that the fourteenth amendment's due process clause was "intended to give the Suprenie Court broad discretion to invalidate state laws" (p. 193), he behieves such discretion should be exercised only to assure black eniancipation and "to help prevent the reeniergence of dangerous sectional tensions" (p. 196). In particular, courts shonld use substantive due process to hold state practices invalid only when those practices are rejected by a consensus of legislation in a substantial majority of other states and are "so extreme, so shocking, that they threaten national unity" (p. 195). Federal courts, therefore, shonld not limit state regulation of matters like capital punishment, pornography, educatimg aliens, and contraception (p. 197).

Few people wonld attenipt a theory of constitutional interpretation in ten pages, and a theory of statutory imterpretation in twenty-five. Posner's ambition can be criticized for resulting in assertion rather than demonstration. More important, two of his premises are highly questionable. One is that public-mterest interpretation (statutory or constitutional) normatively is appropriate only for public-interest legislation and not for interest-group and public-sentiment legislation. The other is that statutory interpretation should never take account of contemporary views. Both premises rest on too constricted a view of the judicial role in the lawniaking process.

Why should it follow from a realist view of the legislative process that what motivated a statute's adoption should forever control its niterpretive course-that "courts should . . . honor the legislative compromise" (p. 282) and ignore current legislative preferences? Posner answers that otherwise judges may effectively repeal legislation and that current legislative preferences are not readily discermible anyway ( $p$. 279). But slavish adherence to past majorities is also problematic. "In1aginative reconstruction" of the original legislative process from dated materials, and ascertaining whether legislation responded to public-interest, public sentiment, or interest-group influences, is at least as difficult as assessnent of current policy. ${ }^{45}$

It also is highly doubtful that legislatures always intend their enactments to govern forever or until there is legislative reconsideration, especially if the adopted laws mcorporate interest-group compromises. Nor do legislators expect judges to ignore the public interest, intervening developments, and public changes of attitude that have not yet been

45. See Easterbrook, supra note 43, at 547-48. I do not think this is enough of a reason to forego the inquiry entirely, but it is certainly enough of a reason not to abjure inquiry into current legislative preference if inquiry into past legislative preference is undertaken. 
enacted into law. Although activist judges may exercise wide interpretive powers to inold legislation in ways that current congressional majorities would not, Posnerian judges may leave intact legislation that is even further out of line with current inajoritarian views. We must choose between active judicial reflection on current policy and passive judicial rehiance on past, unrepealed policy as a proxy for current democratic wishes, unless we behieve conteinporary views are wholly irrelevant to interpreting previously adopted law. Such a behief seems unjustified, however, given the normative priority of current over past majorities and the reality that inertia and agenda limitations, not legislative opposition, often account for failure to update statutes. ${ }^{46}$

Having federal judges act solely as registers of past political compromises also reduces their potential to contribute to the lawmaking process. Posner apparently rejects the Bickel-Wellington-Calabresi tradition, which urges, in varying forms, the recognition of an interactive process between Congress and the federal courts. That tradition urges the federal courts to assess the extent to which past law seems out of step with current majoritarian pohicy or constitutional norms and sometimes to reach statutory or constitutional judgnients that effectively remand the issue for congressional reconsideration..$^{47}$ Even if, for reasons of legitimacy $^{48}$ or workability, ${ }^{49}$ one rejects Calabresi's suggestion that judges nullify obsolete statutes, it does not follow that judges have no role in updatimg a statute's reach. Posner seeks a middle ground that would help carry out legislation as it was initially conceived. But he implicitly rejects another middle ground that would help the legislative process, conceived of as an ongoing process of developinent and alteration of law to which judges legitinıately can contribute. The remanding or provocative function of federal courts no more bypasses the legislative process than does the failure to rethink what is on the statute books. Instead, it inay educate, generate dialogue, and press for democratic reconsideration of dated pohicies.

If federal courts should have a greater interactive role in the legisla-

46. For a sophisticated exploration of the democratic limits that periodic elections impose on the power of a past legislative majority to control the legal options of subsequent legislatures, see Enle, Temporal Limits on the Legislative Mandate (Entrenchment and Retroactivity) (forthcoming in AM. B. FOUND. RES. J.).

47. See generally A. Bickel, The Least Dangerous Branch: The Supreme Court AT THE BAR of Politics (1962); G. Calabresl, supra note 42; Bickel \& Wellington, Legislative Purpose and the Judicial Process: the Lincoln Mills Case, 71 HARv. L. Rev. 1 (1957). For an interesting critique of this school of thought, including some important differences among its disciples, see Weisberg, The Calabresian Judicial Artist: Statutes and the New Legal Process, 35 STAN. L. REv. 213, 241-49 (1983).

48. See Weisberg, supra note 47, at 228, 254; Coffin, The Problem of Obsolete Statutes: A New Role for Courts? (Book Review), 91 YALE L.J. 827, 832-36 (1982).

49. See Coffin, supra note 48 , at $838-39$. 
tive process than Posner believes, then interest-group and public-sentiment legislation should be given different normative weiglit than publicinterest legislation in making interpretive and constitutional judgments. Disparity between past and present perceptions of public interest may be greater witl some types of legislation than with others. It is only because Posner denies the legitimacy of judicial imput that he also believes the original legislative compromise nuust be honored. In short, his attempt to derive the proper judicial function fron 1 his understanding of the legislative process is circular. With respect to interpretation, it begins and ends witl the unexamined assumption that judges sliould follow the original political alignment that produced the statute. ${ }^{50}$ Witl respect to constitutional assessment, it begins and ends with the unexamined assumption that judges should treat all legislation, whether designed to satisfy public sentiment, the public interest, or particular interest groups, with the same degree of deference. In both instances, Posner moves fron1 what is to what ouglit to be, or, more precisely, from what was the political event to what should continue to be the legal result. For Posner, "tlie normative power of the actual"si is not only a description of human behavior, but a prescriptive ginde for federal judges.

If we want federal judges to make public-interest contributions to the lawmaking process, other elements of Posner's judicial philosophy also lose appeal. His discussion of judicial opinions, for example, focuses on litigants, lawyers, judges, and acadermics, but pays little attention to legislators, politicians, and the public. Taking these latter audiences into account, his criticisnis of opimon-writing lose force. Discursive, scholarly opimions that elaborate the implications of competnig regnlatory policies may educate the polity and its representatives and prompt wiser political action. Similarly, single-minded pursuit of more certainty im legal rules ignores the value of deliberately tentative opimions that may attract needed legislative and public attention.

Ironically, Posner's opposition to judicial infusion of contemporary policy also may undermine his objectives of increased judicial restraint and decreased litigation. Judges who decide cases based exclusively on outdated laws may shape the legislative agenda more forcefully than judges who update legislation, because they may remforce unacceptable

50. For a differing view, see Macey, Promoting Public-Regarding Legislation Through Statutory Interpretation: An Interest Group Model, 86 Colum. L. Rev. 223 (1986). Professor Macey urges federal courts to continue to follow their traditional public-interest approach to statutory interpretation, even when construing statutes with interest-group origins. He believes this will reduce interest group influence over the legislative process and encourage Congress to legislate for the broader public welfare.

51. Cohen, The Basis of Contract, 46 HARv. L. REv. 553, 582 (1933) (attributing the phrase to Jellinek). 
approaches that demand correction. Moreover, if legislative action is not forthcoming, outdated law is likely to produce more lawsuits.

Finally, many believe the federal courts should be active leaders, nol just participants, in low law governs our society. ${ }^{52}$ Judge Posner may blanch at the thought, althougli even he finds Brown v. Board of Education "an activist decision, but a justifiable one" (p. 220). ${ }^{53}$ Sometimes, the need to suffuse law with contemporary standards and moral princi. ples is too compelling to ignore.

At the very least, we should not accept Posner's approach until we clearly decide what functions we wislı federal courts to perform, what their relationship to the legislative process ideally should be, and how our need to accommodate continuity and change sliould be filtered through the judicial process. Posner, I behieve, urges an impoverished conception of the federal judicial role.

\section{CONCLUSION}

This Review criticizes two aspects of Posner's economic and political theory. One is his selective and partial focus. The other is his surprisingly formahist reasoning to derive a normative judicial philosophy from positive economic analysis. The two are related, for the normative case is mucli stronger if the cost-benefit metlodology is applied within the closed systein he defines.

Were this book entitled "Some Important Considerations Bearing on Proposals to Reform the Federal Courts," it would be much inore successful than it is. Posner's clamis are much stronger, however, and belie his prefatory caution that the project is suggestive, not exhaustive, and tentative, not definitive (p. vï). The tendency to draw firmer and larger conclusions than his data or analysis will bear, a risk of any social science work, results in the portrayal of intermediate effects or connections as ultimate logical choices. Posner exaggerates the explanatory power of his economic analysis, which is insufficiently systematic and comprehensive to justify his claim. In any event, the economic concep-

52. E.g., Fiss, Foreward: The Forms of Justice, 93 HARv. L. REv. 1 (1979).

53. Posner does not tell us why he finds Brown an example of justifiable activism. This omission may have misled at least one reviewer into concluding that application of Posner's method of constitutional interpretation would result in disapproval of Brown. See Rahdert, Book Review, 58 TEMP. L. Q. 577, 582-83 (1985). Rahdert neglects to mention Posner's approving, if conclusory, reference to Brown. Although I do not disagree with Rahdert that Posner's book has elements of a "position paper" designed to attract support for Posner's elevation to the Supreme Court, id. at 577, faimess does require recognition of his position on Brown. In fact, I suppose his approval of Brown is as much a litmus test for Senate confirmation as his disapproval of Roe v. Wade, 410 U.S. 113 (1973), is a litmus test for a Supreme Court nomination by President Reagan. A more charitable interpretation of his approval of Brown's activism is that it fits within his belief that the fourteenth amendment was designed "to complete the emancipation of the Negro" (p. 193), although it takes something of a liberal, contemporary approach to reach that activist result. 
tion probably is too reductionist to capture the full range of qualities and values that should be considered even in a utilitarian, cost-benefit analysis. Whatever the reason, Posner's analysis does not adequately justify his normative prescriptions.

Posner niay be insufficiently aware of his own ideology and its effect on his social science analysis. For one who has sought to distinguish the positive and normative aspects of economic analysis, ${ }^{54}$ and who previously has been criticized for failing to do so, ${ }^{55}$ that conclusion might seem surprising. But the lack of self-consciousness about choices to be inade pervades the book-choices between quality and quantity, restraint and activism, responsiveness to past and present majorities, and the public interest and political coinpromises. Posner may have a significant blind spot rather than a dehiberate plan to ignore what he knows to be major difficulties with his analysis. After all, blind spots are often covered by ideology.

Posner's ideology focuses on two dominant values-the overarching wortl of economic analysis of law, and the propriety of a limited role for the federal courts. Despite Posner's evident behef that the normative priority of tliese values can be demonstrated, it is tenipting to describe tliem as articles of faith because they seem to guide his analysis rather than derive froin it. Were the two tenets inherently linked, it would at least be easier to understand the jumps from positive to normative analysis, but a confined judicial role is simply not a necessary outgrowtli of economic analysis. ${ }^{56}$ Posner soinetimes separates tlie two values as, for example, when he argues that structural restraint is a contingent, time-and-placebound value. At otler times lie conflates thein, as with his prescriptions

54. See Posner, The Present Situation in Legal Scholarship, 90 YaIE L.J. 1113 (1981); Posner, Utilitarianism, Economics, and Legal Theory, 8 J. LEG. STUD. 103 (1979):

55. See Priest, The New Scientism in Legal Scholarship: A Comment on Clark and Posner, 90 YALE L.J. 1284, 1291 (1981).

56. Judge Easterbrook wlio, like Posner, is a believer in botli economic analysis and a limited version of the federal judicial role, recently clarified his understanding that the two beliefs are not inlierently linked. His Foreword extolling the virtues of liaving judges who appreciate the economic effects of tlieir decisions, see supra note 40, led Professor Tribe to respond that Easterbrook's economic emplrasis too narrowly confined the judicial role in constitutional adjudication. See supra note 19. Easterbrook replied that tlie "difference between us is not so mucl about the role of economics in judging as it is about tlie role of judges in society." Easterbrook, Method, Result, and Authority: A Reply, 98 HARv. L. REv. 622, 627 (1985).

The works of Bruce Ackerman, Frank Michelman, and Guido Calabresi inake clear that not all who find virtue in economic analysis are led to believe in judicial inodesty. See, e.g., B. ACKERMAN, RECONSTRUCTING AMERICAN LAW (1984); Miclielinan, Reflections on Professional Education, Legal Scholarship, and the Law-and-Economics Movement, 33 J. LEgAL EDuc. 197 (1983); Michelinan, The Supreme Court, 1968 Term - Foreword: On Protecting the Poor Through the Fourteenth Amendment, 83 HARv. L. REv. 7 (1969). Compare G. Calabresi, The Costs of ACCIDENTs (1970) and Calabresi \& Melamed, Property Rules, Liability Rules, and Inalienability: One View of the Cathedral, 85 HARv. L. REv. 1089 (1972), with CALABRESI, supra note 42. 
for statutory and constitutional interpretation. This renders the analysis more confusing and more vulnerable than Posner appears to appreciate

In fact, the idea that restraint is a contingent good is fundamentally inconsistent with the idea that a limited interpretive role for the federa. courts is not contingent. Posner finds no inconsistency between approv. ing the activism of John Marshall's Court and the restraint of the Burges Court, because the "historical situation" is a relevant factor (p. 211) What, then, of the Warren Court's activism? And how do we know tha: activism or restraint, or a limited or more expansive interpretive role, is right for the times?

The changes that occurred during Posner's chosen period of analy. sis, from 1960 to 1983 , included much more than caseload growth. A: Posner well recognizes, they included a legal revolution characterized by an expansion of federal rights, in significant part prompted by the federa courts. Moreover, the time period he uses, although it shows a steads growth of federal court business, encompasses both a Court that took ar activist, expansive view of federal court power and a Court that has reemphasized the structural restraint values that Posner commends. I: the scope of the federal judicial role is historically contingent, so shoulc be the economic or social science analysis-at least in its normativi dimensions. The analysis and prescriptions surely cannot depend only on the size of the federal court docket, even if that is a major considera. tion. The assessment must be justified on the basis of the range of soci. ety's needs and on the basis of the contributions the federal courts car make to solving them, taking into account institutional limitations anc the effects on other agencies of government.

This is a complex business and not easily reducible to even the mos powerful theories, especially when the analyst's ideology and historica assessment are either omitted from the analysis or asserted in cursory and conclusory form. Judge Posner's many valuable but partial insight: should be read together with The Federal Courts's economic, social sci ence, and ideological omissions before the political choices behind his recommendations are accepted. 